Hikmah: Journal of Islamic Studies, 16 (1), 2020, 83-99

http://journal.uinjkt.ac.id/index.php/HIKMAH

DOI: 10.47466/hikmah.v16i1.168 | P-ISSN. 2088-2629, E-ISSN. 2581-0146

\title{
ANAK-ANAK DAN HAFALAN AL-QURAN: STUDI METODE MENGHAFAL AL-QURÁN UNTUK ANAK-ANAK
}

\author{
Nurlaila \\ Sekolah Tinggi Agama Islam Negeri Syaikh Abdurrahman Siddik, Indonesia \\ nurlailasupardi@gmail.com
}

\begin{abstract}
This article discusses the method of Qur'an memorization for children based on the age levels. Mushrooming tahfiz programs in schools, this library research elaborates some pivotal consideration that parents should take into account before deciding to take their children into tahfiz program. Qur'an memorization can not be instantly conducted. It need perseverance and persistence in the process of repeating in order the memorization resulted is very strong in the heart. Implementation of proper method in Qur'an memorization will make children attracted in memorizing the Qur'an with no coercion.
\end{abstract}

Keywords: Children; Qur'an; Method; Memorization

\begin{abstract}
Abstrak
Tulisan ini membahas metode menghafal Al-Qurán untuk anak-anak yang sesuai dengan jenjang usianya. Dilatarbelakangi oleh maraknya sekolah-sekolah berprogram tahfiz (menghafal Al-Qurán), kajian dengan metode library research ini sedikit memberikan ulasan beberapa hal penting yang harus dipertimbangkan para orangtua sebelum memutuskan anak-anak mengikuti program hafalan Al-Qurán. Menghafal Al-Qurán tidak bisa dilakukan secara instan. Butuh ketekunan dan kontinuitas dalam proses pengulangannya agar hafalan yang dihasilkan benar-benar kuat. Penggunaan metode menghafal Al-Qurán yang tepat dapat membuat anak-anak tertarik untuk menghafal Al-Qurán tanpa paksaan.
\end{abstract}

Kata Kunci: Anak-anak; Al-Qurán; Metode; Menghafal 


\section{PENDAHULUAN}

Dewasa ini perkembangan tahfizh atau menghafal Al-Qurán meningkat pesat. Banyak para orang tua yang termotivasi bahkan cenderung berambisi anaknya menjadi seorang penghafal Al-Qurán. Terlebih saat seorang Musa La Ode muncul. Musa yang mulai dikenal ketika menjuarai kompetisi Hafizh Indonesia 2014 saat berusia 5,5 tahun, dan kemudian menjadi viral di media sosial saat menjuarai Musabaqah Hifzhil Quran Tingkat Internasional Sharm El Sheikh di Mesir pada medio April 2016 silam. Meskipun meraih juara ketiga ia berhasil menyisihkan 80 peserta dari berbagai belahan dunia yang sebagian besar berusia sepuluh tahun sementara dia baru berusia 7 tahun. ${ }^{1}$ Fenomena Musa ini menambah semangat para orang tua untuk menjadikan anak-anak mereka menjadi seperti Musa, hafal Al-Qurán saat masih belia.

Menghafal Al-Qurán bagi sebagian orang merupakan hal yang sulit. Namun bagi para penghafal Al-Qurán menghafal itu mudah menjaganya yang sulit. Kedua pandangan ini tidak sepenuhnya benar tapi juga tidak sepenuhnya salah. Hal ini dikarenakan proses yang dilalui seorang dalam menghafal Al-Qurán berlangsung seumur hidup. Menghafal AlQurán 30 juz mungkin bisa dilakukan dalam waktu kurang dari sebulan ${ }^{2}$ namun menjaganya agar terus melekat dalam memori penghafalnya berlangsung hingga akhir hayat. $^{3}$

Jika melihat dari sejarah, menghafal Al-Qurán merupakan tradisi awal saat Al-Qurán diturunkan. Melalui hafalan, Al-Qurán diajarkan secara kolosal dan turun temurun. Karenanya benteng bacaan Al-Qurán yang paling kokoh adalah hafalan. ${ }^{4}$ Kesalahan bacaan Al-Qurán bisa dikoreksi melalui hafalan.

Menghafal Al-Qurán bisa dilakukan di berbagai usia. Mulai dari anak balita hingga orang yang sudah lanjut usia. Sebagai contoh Yazeed, Tabarak dan Zeenah asal Iran yang merupakan tiga bersaudara telah hafal Al-Qurán pada usia dibawah lima tahun. ${ }^{5}$ Di negeri kita ada Musa La Ode yang hafal Al-Qurán pada usia lima tahun. Kemudian di usia 40

\footnotetext{
${ }^{1}$ https://www.genpi.co/gaya-hidup/37278/takjub-hafiz-cilik-asal-bangka-menorehkan-prestasi-di-mesir

${ }^{2}$ Ustadz Deden Makhyaruddin, Juara Nasional Tahfidz Al Quran 30 Juz dan Juara Internasional Tafsir Al Quran Bahasa Arabdi Maroko tahun 2011 bisa menghafal Al Quran 30 juz dalam waktu 19 hari (setoran) dan 56 hari untuk melancarkan, lihat https://semangatdakwah.wordpress.com/2015/06/18/8-tips-menghafal-al-quran

${ }^{3}$ Penghafal Al Quran dilarang keras melupakan hafalannya. Nabi SAW bersabda,” Aku telah diperlihatkan pahala-pahala umatku hingga sebuah kayu yang disingkirkan seseorang dari masjid. Aku juga diperlihatkan dosa-dosa umatku. Aku tidak melihat dosa yang lebih besar dibanding sebuah surat atau ayat dari Al Quran yang dihafalkan oleh seseorang, lalu dilupakannya" (Lihat Imam Abu Dawud: Nomor 461; Imam al Turmudzi, Nomor 2917). Menurut Ali Aziz dalam bukunya Mengenal Tuntas Al Quran tentu yang dimaksud dengan hadits ini adalah orang yang sengaja melupakan hafalannya.

${ }^{4}$ Moh. Ali Aziz. 2012. Mengenal Tuntas Al Quran. Surabaya : Imtiyaz, 2012), h.187

${ }^{5}$ Lihat Rahasia Hafal Al Qur'an dari Hafidz Termuda Dunia, (online)available: edupost.id diakses 10 Maret 
tahun, Prof. Dr. Kudang Boro Seminar, M. Sc, seorang Guru Besar Teknik Teknologi Komputer IPB juga berhasil menghafal Al-Qurán 30 juz. ${ }^{6}$

Sebelum Musa La Ode muncul, tahun 2008 dunia dihebohkan dengan kemunculan Husein Thabathaba'i asal Iran yang mampu menghafal Al-Qurán berikut tafsirnya dalam bahasa ibu pada usia lima tahun. Karena kemampuannya itu, Husein diundang ke berbagai negara dan memperoleh gelar Doktor Honoris Causa dari sebuah Islamic Colleege di Inggris.

Program menghafal Al-Qurán tampaknya sekarang tidak lagi menjadi monopoli pesantren khusus tahfizh. Ada banyak rumah tahfizh, begitupun juga sekolah-sekolah umum unggulan yang berbasis Islam atau dikenal dengan istilah Sekolah Islam Terpadu yang menggunakan tahfizh sebagai program unggulan mereka dan kompetensi yang harus dicapai siswanya. Tentu saja ini merupakan suatu tren positif, terutama dalam upaya memelihara keaslian Al-Qurán. ${ }^{7} \quad$ Bercermin kepada para ilmuan muslim di zaman keemasan Islam, seperti Imam Syafi'i, Ibnu Sina, dan seterusnya mereka adalah ilmuan muslim yang berpijak di atas pondasi tahfizh yang kuat. Imam Syafi'i, seorang pendiri madzhab Syafi'iyyah yang cukup berpengaruh di Indonesia, telah hafal Al-Qurán sejak usia tujuh tahun. Begitu juga Ibnu Sina, seorang pakar kedokteran, sudah hafal Al-Qurán sejak usia sembilan tahun. Hal ini menunjukkan bahwa tahfizh Al-Qurán sangat penting sebagai pondasi keilmuan di bidang agama dan ilmu lainnya. Ulama terdahulu mensyaratkan hafalan Al-Qurán sebagai awal pembelajaran sebelum mempelajari ilmu-ilmu lain. ${ }^{8}$

Namun jika melihat kultur dan budaya yang jauh berbeda antara negeri ini dan para ilmuan di zaman keemasan Islam yang notabene di sekeliling mereka telah membudaya praktek menghafal Al-Qurán, lantas apakah menghafal Al-Qurán harus dipaksakan kepada anak hanya demi memenuhi ambisi orangtuanya? Sudahkah para orang tua yang ingin anaknya menjadi seorang penghafal Al-Qurán mempertimbangkan minat dan kemampuan anak?

Semua orang tua pasti bangga anaknya hafal Al-Qurán. Al-Qurán yang merupakan pedoman hidup umat Islam merupakan mukjizat yang tidak semua orang bisa menghafalnya. Seperti yang dikemukakan oleh M. Quraish Shihab bahwa tiada satu bacaan pun yang dibaca oleh ratusan juta orang, baik mereka yang mengerti artinya maupun yang

${ }^{6}$ https:// chanelmuslim.com/ khazanah/ menghafal-quran-saat-usia-40-tahun-inilah-peng-alaman- prof-drir-kudang-boro-seminar-msc,

${ }^{7}$ Fauzan dan Wajdi, Quantum Tahfizh, (Palembang : YKM Press, 2010 ), h. 49

${ }^{8}$ Fauzan dan Wajdi, Quantum Tahfizh......h. 50 
tidak mengerti artinya, bahkan dihafal redaksinya, huruf demi huruf seperti halnya AlQurán.'

\section{METODE}

Dengan menggunakan metode library research tulisan ini bemaksud untuk lebih memperkaya lagi pemahaman kita tentang bagaimana metode menghafal Al-Qurán yang tepat untuk anak-anak sesuai dengan jenjang usianya. Harapan penulis semoga kita bisa mempertimbangkan kemampuan dan minat anak kita ketika menginginkan mereka menjadi seorang penghafal Al-Qurán.

\section{HASIL DAN PEMBAHASAN}

\section{Keutamaan Menghafal Al-Qurán}

Sudah menjadi hal umum bahwa orang yang menghafal Al-Qurán pasti akan banyak membacanya. Ia akan terus-menerus membacanya hingga kuat hafalannya, dan ia akan selalu melakukan muraja'ah (mengulang-ulang kembali) hafalannya, karena boleh jadi ada yang terlupakan olehnya seiring berjalannya waktu.

Dalam Al-Qurán banyak dijelaskan tentang keutamaan orang yang membaca AlQurán seperti termuat dalam surat Fathir ayat $29-30^{10}$ yang berbunyi,

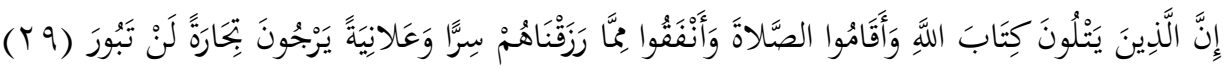

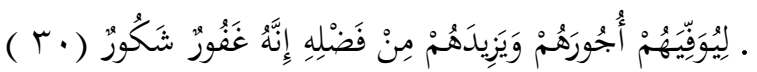

$$
\begin{aligned}
& \text { ( }
\end{aligned}
$$

Artinya:

29. Sesungguhnya orang-orang yang selalu membaca kitab Allah dan mendirikan shalat dan menafkahkan sebahagian dari rezki yang Kami anugerahkan kepada mereka dengan diam-diam dan terang-terangan, mereka itu mengharapkan perniagaan yang tidak akan merugi,

30. agar Allah menyempurnakan kepada mereka pahala mereka dan menambah kepada mereka dari karunia-Nya. Sesungguhnya Allah Maha Pengampun lagi Maha Mensyukuri.

Kemudian dalam surat Fathir ayat 32 yang berbunyi, ${ }^{11}$

\footnotetext{
${ }^{9}$ M. Quraish Shihab, Mukjizat Al Quran: Ditinjau dari Aspek Kebahasaan, Isyarat Ilmiah, dan Pemberitaan Gaib (Jakarta : Mizan, 2007), h. 50

${ }^{10}$ Alquranul Karim (Mushaf Wakaf), (Tangerang: FPQ, 2012), h. 437
} 


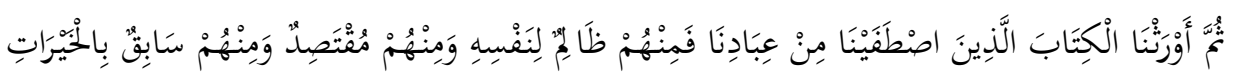

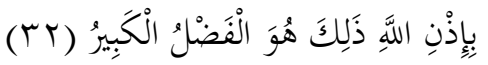

Artinya: Kemudian kitab itu Kami wariskan kepada orang-orang yang Kami pilih di antara hamba-hamba Kami, lalu di antara mereka ada yang menganiaya diri mereka sendiri dan di antara mereka ada yang pertengahan dan diantara mereka ada (pula) yang lebih dahulu berbuat kebaikan dengan izin Allah. Yang demikian itu adalah karunia yang amat besar.

Dalam hadits pun banyak dikemukakan keutamaan orang yang membaca Al-Qurán seperti yang diriwayatkan Aisyah ra,

$$
\text { عن عائشة رضى الله عنها : قالت: قال رسول الله صلى الله عليه وسلم: الما هر با لقرأن مع }
$$

Artinya: Diriwayatkan dari Aisyah ra, dia berkata: Rasulullah Saw, pernah bersabda," Orang yang membaca Al-Qurán dengan fasih dan lancar akan dikelompokkan dengan orang-orang yang mulia. Orang yang membaca Al-Qurán dengan tidak lancar namun dia tetap bersusah payah untuk membacanya maka dia mendapat dua pahala ${ }^{12}$

Rauf $^{13}$ menyebutkan setidaknya ada 5 hal yang menunjukkan pentingnya menghafal Al-Qurán, yaitu

\section{Menjaga kemutawatiran Al-Qurán}

Menjaga kemutawatiran Al-Qurán artinya menjaga keorisinilan Al-Qurán dengan salah satunya mempelajari Al-Qurán yang diturunkan kepada Muhammad Saw. Muhammad Saw menghafal Al-Qurán yang diterima melalui malaikat Jibril, dan disimak oleh malaikat Jibril secara menyeluruh. Kemudian para sahabat menghafal Al-Qurán secara sempurna yang disimak oleh Nabi Muhammad SAW. Kemudian terus ke generasi selanjutnya sampai sekarang tanpa putus.

Al-Qurán diturunkan kepada Nabi Muhammad Saw dengan menggunakan bahasa Arab, sebagai mukjizat yang tidak bisa tertandingi oleh bangsa Arab. Membacanya merupakan ibadah dan penukilannya kepada kita secara mutawattir (jalan periwayatannya berkesinambungan, tidak terputus dan melalui jalan yang paling terpercaya, sehingga

${ }^{11}$ Alquranul Karim......., h.438

${ }^{12}$ Imam Al Mundziri, Ringkasan Shahih Muslim (diterjemahkan oleh Achmad Zaidun), Jakarta : Pustaka Amani, 2003), h. 1254

${ }^{13}$ Abdul Aziz Abdur Rauf, Menghafal Al Quran Itu Mudah (Jakarta : Markaz Al Quran, 2009), h. 32-45 
terpelihara keaslian dan keotentikannya). Allah Swt berfirman mengenai hal ini dalam surah As Syu'ara ayat 192-195

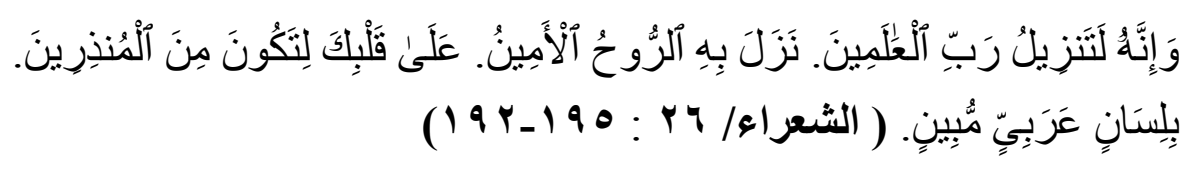

Artinya : (192) dan Sesungguhnya Al-Qurán ini benar-benar diturunkan oleh Tuhan semesta alam, (193) Dia dibawa turun oleh Ar-Ruh Al-Amin (Jibril),(194) ke dalam hatimu (Muhammad) agar kamu menjadi salah seorang di antara orang-orang yang memberi peringatan, (195) dengan bahasa Arab yang jelas.

Para ulama salaf sungguh besar perhatiannya untuk merealisasikan kepentingan ini. Mereka telah berhasil mengabadikan sanad pengajaran Al-Qurán sejak zaman Nabi Muhammad, sahabat, tabi'in dan tabi'tabi' in sampai sekarang. Lembaga-lembaga Al-Qurán yang masih menjaga kualitas pengajaran Al-Qurán dapat dipastikan masih menyimpan sanad ini seperti dapat kita temui di tanah air ini atau di Timur Tengah. Proses belajar AlQurán bersanad atau yang disebut dengan talaqqi, akan menjadikan pelajar Al-Qurán benar-benar menguasai Al-Qurán secara baik dan benar, karena cara inilah yang mampu menjaga orisinalitas Al-Qurán.

\section{Meningkatkan kualitas umat}

Al-Qurán merupakan sumber ilmu pengetahuan dan petunjuk bagi manusia. Kualitas umat akan terangkat jika nilai-nilai dalam Al-Qurán benar-benar direalisasikan dalam kehidupan. Tidak akan terangkat kualitas umat ini kecuali dengan Al-Qurán. Kualitas umat yang terangkat seiring dengan kemuliaan yang Allah berikan kepada mereka yang menjadikan Al-Qurán sebagai pedoman hidup sebagaimana sabda Rasulullah yang diriwayatkan Muslim dari Umar bin Khattab ra,

$$
\begin{aligned}
& \text { ان نا فع بن عبد الحا رث لقى عمر بعسفا ن. وكا ن عمر يستعمله على مكة. عن عا مر بن وا ثلة، } \\
& \text { فقال: من استعملت على أهل الوادى؟ فقال : ابن أبزى ـ قال ومن ابن ابزى؟ قال : مولى من موا لينا. قال: } \\
& \text { فا ستخلفت عليهم مولى؟ قال انه قا رئ لكتاب الله عز وجل ـ وانه عا لم بالفرائض. قال عمر: ان نبيكم } \\
& \text { صلى الله عليه و سلم قد قال إن الله يرفَع بهذَاالكتاب أَقَواماويضع به أَخرين (رواه مسلم) }
\end{aligned}
$$

Artinya: Bersumber dari Amir bin Watsilah; sesungguhnya Nafi' bin Abdul Harits bertemu Umar di Asfan. Umar memang menugaskan Nafi' di Makkah. Nafi' bertanya:"Siapa yang Anda tugaskan mengurus penduduk Al Wadi?" Umar menjawab:"Ibnu Abza”. Nafi' bertanya: “Siapa itu dia Ibnu Abza?”Umar menjawab: "salah

\footnotetext{
${ }^{14}$ Alquranul Karim (Mushaf Wakaf), (Tangerang: FPQ, 2012), h. 375
} 
seorang budakku”. Nafi' berkata: "Jadi Anda menugaskan seorang budak sebagai wakil Anda?"Umar berkata: "Sesungguhnya Ibnu Abza itu adalah seorang yang pandai membaca kitab Allah Yang Maha Mulia Lagi Maha Agung. Disamping itu dia pintar ilmu-ilmu faraidh."Selanjutnya Umar juga mengatakan: “Adapun sesungguhnya Nabimu Saw pernah bersabda:"Sesungguhnya dengan Al-Qurán-lah Allah mengangkat beberapa kaum dan menurunkan derajat kaum-kaum yang lainnya”. ${ }^{15}$

\section{Menjaga terlaksananya sunnah-sunnah Nabi Muhammad SAW}

Sebagian ibadah yang dilakukan Nabi Muhammad SAW, ada yang sangat terkait dengan praktek menghafal Al-Qurán. Beliau membaca surat-surat Al-Qurán ketika shalat Jumat, subuh, ied dan lain-lain. Beliau membaca surat pilihan dalam sholat. Seperti surat Sajadah pada raka'at pertama sholat subuh, dan Al Insan di raka'at kedua pada hari Jumat. Hal ini dijelaskan dalam hadits yang diriwayatkan oleh Ibnu Abbas ra.,

$$
\begin{aligned}
& \text { : ( الم عن ابن عباس رضي الله عنه ان النبي صلى الله عليه وسلم كا ن يقرأ في صلاة الفجر يوم الجمعة } \\
& \text {. تنزيل..) السجدة . و ( هل أتى على الأ نسا ن حين من ادهر) (رواه مسلم) }
\end{aligned}
$$

Artinya: Diriwayatkan dari Ibnu Abbas ra, bahwasanya Nabi Saw. Pada shalat subuh di hari Jumat pernah membaca” Alif Laam Miim Tanziilu” yaitu surat As Sajadah dan "Hal ataa 'alal Insaani hiinum minad dahri”' ${ }^{16}$

Dengan menghafal Al-Qurán, kebiasaan Nabi Muhammad SAW bisa ditiru yaitu mengulang hafalan ketika shalat. Dengan demikian ayat yang dibaca saat sholat tidak hanya surat-surat pendek dalam juz amma. Menjadikan hafalan Al-Qurán sebagai bacaan shalat bisa menjadi alternatif untuk mengulang hafalan bagi para huffazh untuk mengikuti sunnah Nabi.

\section{Menjauhkan mukmin dari aktifitas laghwu (sia-sia)}

Dengan menyibukkan diri membaca Al-Qurán, seorang mukmin telah terhindar dari aktifitas yang tidak bernilai di sisi Allah SWT. Membaca Al-Qurán dan menghafalnya tidak hanya bernilai ibadah, namun juga mampu memberikan arus positif dan mendapatkan karunia Al-Qurán. Aktivitas membaca Al-Qurán apalagi dengan menghafalnya akan menghindari si pembaca dari perbuatan yang sia-sia dan membuang waktu. Ia akan senantiasa terus menerus berinteraksi dengan Al-Qurán karena Al-Qurán sudah terikat secara abadi dalam hatinya.

${ }^{15}$ An Naisabury, Shahih Muslim Juz I ( diterjemahkan oleh Adib Bisri Mustofa) (Semarang: As Syifa, 1992), h.

${ }^{16}$ Imam Al Mundziri, Ringkasan Shahih Muslim.... h. 231 


\section{Melestarikan budaya salafus shalih}

Apabila dikaji sejarah kehidupan orang-orang shalih zaman dahulu, akan diperoleh gambaran kecemerlangan mereka dalam hal pengetahuan maupun ketaqwaan kepada Allah Swt. Diantara kecermelangan itu terlihat perhatian yang besar terhadap kitab Allah yaitu Al-Qurán. Fenomena ini terlihat dari semangat mereka berlomba-lomba menghafal AlQurán, membacanya dalam shalat dan pada kesempatan-kesempatan lain, sampai-sampai mereka merelakan kenikmatan tidur mereka di malam hari demi melaksanakan tahajud dengan membacanya di malam-malam terakhir dan memanjatkan doa kepada Dzat yang Maha Perkasa lagi Maha Pengampun. Hal serupa ini bukanlah kondisi yang jarang terjadi, bahkan tersebut suatu riwayat yang menyatakan bahwa orang yang melewati rumah-rumah para sahabat di malam hari pasti akan mendengarkan suara dengungan seperti dengungan lebah. Dan tingkat keutamaan di kalangan para sahabat diukur dari banyak sedikitnya hafalan Al-Qurán mereka. ${ }^{17}$

Satu hal yang perlu diketahui adalah bahwa pembelajaran Al-Qurán yang mereka lakukan tidak terbatas pada kemampuan membacanya saja, lalu selesai. Namun mereka juga memberikan perhatian pada praktek menghafal dan memahaminya. Proses membimbing anak untuk menghafal Al-Qurán mereka lakukan sejak dini, sehingga banyak tokoh-tokoh ulama' yang telah hafal Al-Qurán sebelum usia akil baligh, seperti Imam Syafi'i yang hafal Al-Qurán 30 juz pada usia 9 tahun, Imam Malik yang hafal Al-Qurán 30 juz pada usia 10 tahun, dan lain sebagainya.

\section{Perkembangan Tahfizh Al-Qurán Di Indonesia}

M. Syatibi menerangkan bahwa tradisi menghafal Al-Qurán di Indonesia telah berlangsung lama. Pada awalnya dilakukan oleh para ulama yang belajar di Timur Tengah melalui guru-guru mereka. Kecenderungan untuk menghafal Al Quran kian meningkat. Para alumni Timur Tengah, khususnya dari Hijaz (Mekah-Madinah) membentuk lembaga-lembaga tahfizh Al-Qurán dengan mendirikan pondok pesantren khusus tahfizh atau membelajarkan tahfizh Al-Qurán di pondok pesantren yang telah ada. Diantaranya KH. Muhammad Sa'id bin Ismail di Sampang Madura, KH. Muhammad Munawwar di Gresik, KH. Muhammad Mahfuzh At-Tarmasi di Pacitan, KH. Muhammad Munawwir Krapyak Yogyakarta, KH. Dahlan Khalil Rejoso Rembang. Dari kelima ulama inilah berkembang para huffazh dan pesantren tahfizh di Indonesia. Ulama lain yang dikenal hafal Al-Qurán tetapi tidak menjadi sumber sanad dalam bidang ini diantaranya $\mathrm{KH}$.

\footnotetext{
${ }^{17} \mathrm{Abu}$ 'Abd-i'Rahman, Pedoman Menghayati dan Menghafal Al Quran (diterjemahkan oleh Mohammad Handoko Imam Prakoso), (Jakarta : Hadi Press, 1997), h. 46
} 
Khalil Bangkalan dari Madura, KH. Ahmad Dahlan Yogyakarta, dan KH. Hasyim Asy'ari dari Jombang. ${ }^{18}$

Menghafal Al-Qurán atau lebih dikenal dengan istilah tahfizh memiliki dua hal yang harus dipenuhi, yakni menghafal dalam ingatan dan bisa mengucapkannya kembali di luar kepala tanpa membaca Al-Qurán atau catatan lain. Di Indonesia terutama di pulau Jawa banyak sekali pesantren-pesantren yang memiliki tujuan dan visi untuk mendidik dan mencetak generasi muda yang hafal Al-Qurán. Seperti yang penulis singgung di awal, kemunculan Sekolah Islam Terpadu atau yang dikenal dengan istilah SDIT turut membantu lahirnya generasi muda yang hafal Al-Qurán. Apalagi sekarang rumah tahfizh juga berdiri dimana-mana menambah pilihan bagi para orangtua untuk membantu anakanaknya hafal Al-Qurán.

\section{Metode Menghafal Al-Qurán Untuk Anak-Anak}

Muhammad Ratib An-Nabilsi mengatakan dari hasil dan pengamatannya dalam bidang pendidikan, ia meyakini bahwa jenjang umur yang paling pokok bagi anak untuk lebih mudah belajar dari suatu kebiasaan, budaya, keyakinan, dan hal-hal yang baik dan lurus, adalah ketika anak masih dalam asuhan dan ayunan ibunya, kemudian umur ketika telah memasuki bangku pendidikan dasar (SD). ${ }^{19}$ Dari penjelasan Nabilsi dapat diketahui bahwa tahapan usia anak-anak menentukan cara ia memasukkan informasi ke dalam memorinya. Terlebih informasi tersebut adalah ayat-ayat Al-Qurán. Dalam tulisan ini penulis akan mencoba untuk menggambarkan metode menghafal Al-Qurán sesuai dengan jenjang usia anak-anak.

\section{Metode Menghafal untuk Anak Usia 0-2 Tahun}

Dalam ilmu psikologi perkembangan, menurut Piaget usia perkembangan 0-2 tahun adalah masa sensorik-motorik. Pada masa ini sang bayi menyusun pemahaman dunianya dengan mengkoordinasikan pengalaman indrawi sensorik (melihat dan mendengar) dengan gerakan motorik mereka (menyentuh). Maka stimulus yang diterima adalah stimulus indrawi, sehingga jika menginginkan stimulus untuk menjadi bekal anak menghafal AlQurán adalah dengan memperdengarkan Al-Qurán kepada anak, baik secara langsung (talqin) maupun melalui MP3. ${ }^{20}$

\footnotetext{
${ }^{18}$ Muhammad Makmun Rasyid, Kemukjizatan Menghafal Al Quran, (Jakarta: PT Elex Media Komputindo, 2015), h. xix

${ }^{19}$ Sa'ad Riyadh, Metode Tepat Agar Anak Hafal Alquran (alih bahasa Isnaini Bambang H.N dan Arif Manggala), ( Solo: Pustaka Arafah, 2016), h.67

${ }^{20}$ Nurul Qomariyah dan Muhammad Irsyad, Metode Cepat dan Mudah Agar Anak Hafal Al Quran. Yogyakarta : Semesta Hikmah, 2016), h. 35
} 
Sebagai tambahan cobalah untuk membiasakan memutar kaset murattal Al-Qurán disetiap waktu, sebelum anak tidur, ketika bermain dan bangun tidur. Usahakanlah dalam usia ini bacaan Al-Quránlah yang paling banyak didengar oleh anak. Dengan melakukan ini, diharapkan bacaan Al-Qurán sudah terekam kuat dalam ingatannya meskipun ia belum bisa berbicara. Lebih bagus lagi, jika yang membaca Al-Qurán tersebut adalah kedua orangtuanya. Karena anak sudah terbiasa dekat dengan lingkungan yang mencintai AlQurán.

\section{Metode Menghafal untuk Anak Usia 2-5 Tahun}

Ahsin W., dalam Nurul dan Irsyad mengungkapkan bahwa penting bagi orang tua memilih metode yang tepat dalam mendidik anak mereka untuk menghafal Al-Qurán terlebih di usia dini. Saat anak baru bisa berbicara metode menghafal yang bisa digunakan adalah metode sima'i atau talqin, yakni anak mendengar bacaan ayat Al-Qurán yang akan dihafalkan dengan mendengar bacaan secara langsung dari orang tua. Orang tua membacakan satu ayat secara berulang-ulang, kemudian anak mengulang ayat tersebut hingga mampu menghafal dengan lancar. Jika telah lancar baru dilanjutkan ke ayat berikutnya. ${ }^{21}$ Namun metode sima'i atau talqin juga bisa digunakan untuk anak-anak yang belum bisa membaca $\mathrm{Al}$-Qurán dengan lancar. Hal ini seperti yang dilakukan oleh orang tua Musa La Ode. ${ }^{22}$ Namun metode ini membutuhkan kesabaran yang lebih untuk para orang tua yang ingin anaknya hafal Al-Qurán sejak dini.

\section{Metode Menghafal Al-Qurán untuk anak usia 6-13 tahun}

Pada usia ini anak sudah bisa dididik mandiri dalam belajar membaca maupun menghafal Al-Qurán. Untuk yang belum bisa membaca Al-Qurán dengan lancar, tetap bisa menghafal Al-Qurán dengan metode sima’i atau dengan mendengar kaset/video murattal, namun tetap di bawah pengawasan guru yang ahli dalam bacaan Al-Qurán karena hal ini terkait dengan kualitas bacaan. Jika anak dibiarkan menghafal sendiri maka hafalan yang ada tidak jelas benar salahnya.

Untuk anak yang sudah lancar dan fasih bacaan Al-Quránnya bisa memilih metode menghafal mana yang paling nyaman untuknya. Setelah anak hafal, sangat bagus kiranya untuk langsung menyetorkan hafalannya secara langsung atau talaqqi dengan guru yang bagus bacaan Al-Quránnya.

Adapun metode menghafal Al-Qurán yang bisa digunakan oleh anak usia 6-13 tahun akan diuraikan di bawah ini, bisa saja dipilih salah satu diantaranya yang dianggap sesuai, atau dipakai semua sebagai variasi untuk menghilangkan kejenuhan. Metode-metode

\footnotetext{
${ }^{21}$ Nurul Qomariyah dan Muhammad Irsyad, Metode Cepat dan Mudah.....h. 105

${ }^{22}$ Ainun Mahya dan Arnina P, Musa Si Hafiz Cilik Penghafal Alquran (Depok: Huta Publisher, 2016), h. 46
} 
berikut pada umumnya sudah digunakan oleh para penghafal Al-Qurán. Metode-metode tersebut antara lain ialah $:^{23}$

\section{Metode Wahdah}

Menghafal dengan metode wahdah yaitu menghafal satu persatu terhadap ayatayat yang hendak dihafalnya. Untuk mencapai hafalan awal, setiap ayat bisa dibaca sebanyak sepuluh kali, atau dua puluh kali, atau lebih sehingga proses ini mampu membentuk pola dalam bayangannya.

\section{Metode Kitabah}

Kitabah artinya menulis. Pada metode ini penghafal harus menulis ayat-ayat yang akan dihafalnya pada secarik kertas yang telah disediakan untuknya. Kemudian ayat-ayat tersebut dibacanya sehingga lancar dan benar bacaannya, lalu dihafalkannya. Menghafalnya bisa dengan metode wahdah, atau dengan berkalikali menuliskannya sehingga dengan berkali-kali menuliskannya ia dapat sambil memperhatikan dan sambil menghafalkannya dalam hati.

\section{Metode Sima’i}

Sima’i artinya mendengar. Menghafal dengan metode sima’i ialah mendengarkan sesuatu bacaan untuk dihafalkannya. Metode ini akan sangat efektif bagi penghafal yang mempunyai daya ingat ekstra, terutama bagi penghafal tunanetra, atau anak-anak yang masih di bawah umur yang belum mengenal tulis baca AlQurán Metode ini dapat dilakukan dengan dua alternatif:

a. Mendengar dari guru yang membimbing, terutama bagi penghafal tunanetra, atau anak-anak. Dalam hal seperti ini, instruktur dituntut untuk lebih berperan aktif, sabar dan teliti dalam membacakan dan membimbingnya, karena ia harus membacakan satu per satu ayat untuk dihafalnya, sehingga penghafal mampu menghafalnya secara sempurna. Setelah lancar, baru kemudian dilanjutkan dengan ayat berikutnya.

b. Merekam terlebih dahulu ayat-ayat yang akan dihafalkannya ke dalam pita kaset sesuai dengan kebutuhan dan kemampuannya. Kemudian kaset diputar dan didengar secara saksama sambil mengikutinya secara perlahan-lahan. Kemudian diulangi lagi dan diulangi lagi, dan seterusnya menurut kebutuhan sehingga ayat-ayat tersebut benar-benar hafal di luar kepala. Setelah hafalan dianggap cukup mapan barulah berpindah kepada ayat-ayat berikutnya dengan cara yang sama, dan demikian seterusnya. Metode ini akan sangat

\footnotetext{
${ }^{23}$ Ahsin W. Al Hafidz, Bimbingan Praktis Menghafal Al Quran (Jakarta : Bumi Aksara, 2009), h. 63-66
} 
efektif untuk penghafal tunanetra, anak-anak, atau penghafal mandiri, atau untuk takrir (mengulang kembali) ayat-ayat yang sudah dihafalnya. Tentunya penghafal yang menggunakan metode ini, harus menyediakan alat-alat bantu secukupnya, seperti tape-recorder, pita kaset, dan lain-lain.

\section{Metode Gabungan}

Metode ini merupakan gabungan antara metode pertama dan metode kedua, yakni metode wahdah dan metode kitabah. Hanya saja kitabah (menulis) di sini lebih memiliki fungsional sebagai uji coba terhadap ayat-ayat yang telah dihafalnya. Maka dalam hal ini, setelah penghafal selesai menghafal ayat yang dihafalnya, kemudian ia mencoba menuliskannya di atas kertas yang telah disediakan untuknya dengan hafalan pula. Jika ia telah mampu mereproduksi kembali ayat-ayat yang dihafalnya dalam bentuk tulisan, maka ia bisa melanjutkan kembali untuk menghafal ayat-ayat berikutnya, tetapi jika penghafal belum mampu mereproduksi hafalannya ke dalam tulisan secara baik, maka ia kembali menghafalkannya sehingga ia benar-benar mencapai nilai hafalan yang valid. Demikian seterusnya. Kelebihan metode ini adalah adanya fungsi ganda, yakni berfungsi untuk menghafal dan sekaligus berfungsi untuk pemantapan hafalan. Pemantapan hafalan dengan cara ini pun akan baik sekali, karena dengan menulis akan memberikan kesan visual yang mantap.

Metode Jama'

Yang dimaksud dengan metode ini, ialah cara menghafal yang dilakukan secara kolektif, yakni ayat-ayat yang dihafal dibaca secara kolektif, atau bersama-sama, dipimpin oleh seorang instruktur. Pertama, instruktur membacakan satu ayat atau beberapa ayat dan siswa menirukan secara bersama-sama. Kemudian instruktur membimbingnya dengan mengulang kembali ayat-ayat tersebut dan siswa mengikutinya.

Sulaeman menyebutkan menghafal Al-Qurán dengan metode yang menyenangkan akan berpengaruh baik pada perkembangan jiwa seseorang. ${ }^{24}$ Selain dari beberapa metode di atas ada beberapa metode yang bisa jadi pilihan bagi yang mulai menghafal Al-Qurán. Metode-metode tersebut menurut Fauzan dan Wajdi adalah sebagai berikut: ${ }^{25}$

${ }^{24}$ Dina Y. Sulaeman, Doktor Cilik Hafal dan Paham Al Quran, (Depok : Pustaka Iman, 2008), h. 138

${ }^{25}$ Fauzan dan Wajdi, Quantum Tahfizh.... h.145 
Titian Ingatan

Adalah metode mengelola ingatan dengan menggunakan akronim yang memudahkan pemanggilan kembali data atau informasi yang telah tersimpan sebelumnya.

Berikut contoh membuat titian ingatan untuk surah Al Waqiah:

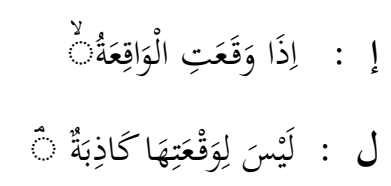

Potret

Metode potret yaitu persis memfotokopi apa yang dilihat dan dibaca, baik yang menyangkut tulisan (khat utsmani), fonetik, maupun tata letak dan sekuensnya. Metode ini dilakukan menggunakan Al-Qurán pojok, yaitu Al-Qurán yang pojok terakhir tepat di akhir ayat terakhir dan tidak tersambung. Jumlah satu juz adalah 20 halaman. Oleh sebab itu, disarankan untuk hanya menggunakan satu model Al-Qurán secara tetap agar tidak berubah-ubah strukturnya.

TTS (Teka-teki Silang)

Dalam metode ini ada satu atau dua kata dari satu ayat kita hilangkan, yang dikosongkan diharuskan penghafal untuk mengingatnya. Misalnya:

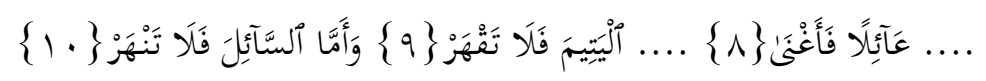

Audio

Metode menghafal Al-Qurán dengan mendengarkan bacaan para qari’ melalui kaset, MP3, dan lain-lain.

Cantol

Metode dengan membuat cantolan, mengasosiasikan dengan materi yang dihafal, mengimajinasikan secara kreatif, dan mengulanginya bila diperlukan.

Contoh:

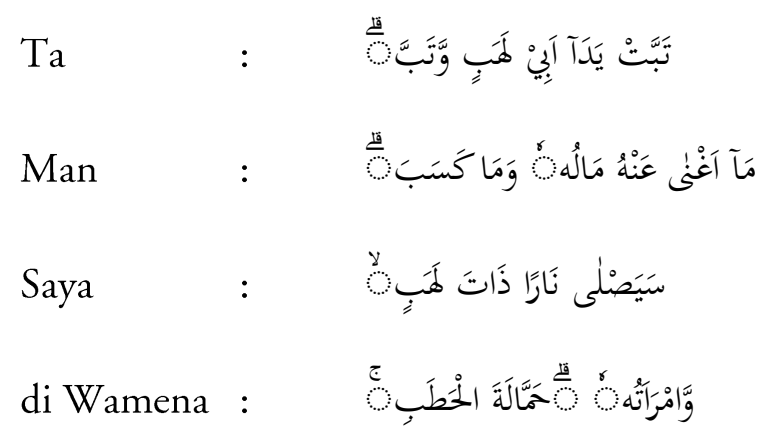




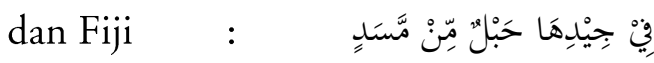

One day one ayat

1 ayat $\mathrm{x} 1$ hari $\mathrm{x} 12$ bulan $=365$ ayat

Gerakan

Menghafal sambil melakukan suau gerakan sangat membantu mengaktifkan memori. Otak kita memiliki satu pusat kecerdasan yang disebut bodilykinesthetyc-intelligence atau kecerdasan gerak. Dengan melakukan gerakan tertentu akan memicu pusat kecerdasan ini aktif. Lebih dari itu, gerakan dapat membuat otot-otot kita lebih rileks dan santai. Gerakan dapat membangkitkan semangat, mengusir kemalasan dan kejenuhan serta menyehatkan.

Kisah

Metode ini bisa digunakan ketika menghafal surah-surah yang memuat kisahkisah para Nabi maupun kelompok tertentu. Contohnya bisa ditemukan dalam surah al Kahfi. Dalam surah ini terdapat kisah tentang Ashabul Kahfi yang tidur selama 309 tahun tanpa disadari setelah berlindung di sebuah gua karena lari dari kejaran penguasa lalim yang kafir (ayat 9-26). Kisah ini sangat menarik sehingga apabila dipahami jalan ceritanya terlebih dahulu akan mudah menghafalkan rangkaian ayat-ayat yang menceritakan kisah itu.

Lima ayat (satu hari lima ayat)

Metode menghafal lima ayat pertama kali diajarkan Jibril AS kepada Nabi Muhammad SAW dalam penurunan Al-Qurán secara berangsur-angsur. Memang Al-Qurán diturunkan bukan hanya lima ayat, namun kebanyakan nabi menerimanya seperti itu dari Jibril, seperti surah Al 'Alaq, Ad Duha, Al Muzzammil, dan lain-lain.

Keberhasilan metode yang digunakan dalam menghafal Al-Qurán tentunya juga didukung oleh lingkungan dan dukungan dari orang-orang tercinta. Untuk anak-anak, keteladanan dari orangtua jelas menjadi faktor utama. Yang harus dipahami oleh para orangtua yang memang ingin anaknya hafal Al-Qurán, bawalah anak dalam suasana yang cinta Al-Qurán. Jadikan bacaan Al-Qurán sebagai bacaan utama. Hiasi hari-harinya dengan senantiasa mendengarkan Al-Qurán. Jadikan diri sebagai contoh bagi anak untuk mencintai Al-Qurán. Ajak anak untuk menghadiri halaqah-halaqah Al-Qurán karena dengan demikian ia akan termotivasi untuk membaca dan menghafal Al-Qurán apalagi jika dilakukan bersama orang-orang yang dicintainya dan teman sebayanya. Seorang Musa La Ode, Husein Thabathaba’i yang hafal Al-Qurán saat usia dini, tidak muncul begitu saja. Mereka tumbuh didampingi oleh orangtua maupun kerabat yang cinta Al-Qurán dan 
senantiasa membudayakan membaca dan mengajarkan Al-Qurán di lingkungan sekitar mereka.

Hal yang juga harus diperhatikan bagi para orangtua bahwa menjadikan anak mau menghafal Al-Qurán bukanlah dengan cara paksa apalagi dengan menyakiti. Tapi dengan terlebih dahulu menumbuhkan rasa cinta Al-Qurán dalam dirinya akan membuatnya mau membaca, menghafal dan memahami Al-Qurán dengan sendirinya. Rasa cinta itu hanya akan muncul jika orang-orang disekeliling anak juga mencintai Al-Qurán. Setelah hafalpun, menjaga hafalannya juga menjadi tugas bersama, yaitu dengan selalu berusaha meluangkan waktu untuk mendengar hafalannya atau membawanya talaqqi ke guru AlQurán yang mumpuni untuk menyimak hafalannya, menemaninya ke majelis-majelis AlQurán, memberi hadiah saat ia berhasil menghafal dengan lancar dan membangun komunikasi dengannya berkaitan dengan keutamaan dalam menghafal dan berinteraksi dengan Al-Qurán.

Sa'ad Riyadh mengungkapkan ketika membimbing anak agar hafal Al-Qurán ada beberapa hal yang bisa kita jadikan sebagai tolak ukur dalam mengenali karakteristik anak, yaitu: $^{26}$

a. Awalilah dengan dialog dan pengantar sebelum memulai bimbingan menghafal Al-Qurán. Jangan lupa sesuaikan dengan jenjang kemampuan sang anak. Perlu dipahami oleh setiap pendidik bahwa anak bukanlah wadah yang bisa diisi begitu saja dengan ilmu tanpa ada pendahuluan terlebih dahulu.

b. Pilihlah pengantar yang tepat dengan metode penyampaian yang cocok dan sesuai dengan karakter si anak. Karena ada anak yang senang dengan mendengar, membaca langsung dengan mushaf atau hanya senang ketika melihat saja.

c. Perhatikan daya tahan konsentrasi setiap anak. Ketahanan konsentrasi seorang anak biasanya hanya beberapa menit saja, dan bisa dihitung dari umurnya masing-masing ditambah 2 menit. Contohnya, anak yang berumur 6 tahun itu tidak mampu berkonsentrasi dalam waktu lebih dari 6 hingga 8 menit saja, dan selebihnya anak tersebut perlu untuk sesekali istirahat atau berpindah ke aktivitas lain, kemudian baru bisa berkonsentrasi dan menghafal kembali.

d. Penuhilah kebutuhan seorang anak untuk bermain dan bersenang-senang, jangan jadikan menghafal Al-Qurán sebagai satu alasan untuk melarang anak bermain. Jika mereka membandingkan antara Al-Qurán dengan bermain, pasti mereka akan lebih cenderung memilih dan mengutamakan kebutuhannya yaitu bermain daripada menghafal.

${ }^{26}$ Sa' ad Riyadh, Metode Tepat Agar Anak Hafal Alquran.....h. 25 
e. Penuhilah kebutuhan gizi anak dengan mengonsumsi makanan yang menyehatkan, karena akan membantunya untuk lebih berkonsentrasi dan menghafal Al-Qurán dengan baik serta lebih menguatkannya ketika muraja’ah (mengulanginya).

Ciptakanlah lingkungan yang kondusif dan mendukung serta suasana yang tenang dan tidak penuh emosional, sehingga anak didik bisa merasakan keamanan, kenyamanan dan ketenangan. Hal itu akan sangat membantu mereka untuk lebih mencintai Al-Qurán dan menghafalnya.

\section{PENUTUP}

Menghafal Al-Qurán bukanlah pekerjaan instan. Butuh keinginan kuat dan keistiqomahan yang lebih dari pekerjaan lain. Apalagi jika sebuah keluarga menginginkan memiliki keturunan penghafal Al-Qurán. Harus ada kerjasama yang kuat antara kedua orangtua, guru Al-Qurán dan lingkungan yang cinta Al-Qurán. Jika kerjasama itu solid akan menghasilkan anak-anak yang cinta Al-Qurán sejak dini. Bagi siapapun yang hendak membimbing anak-anak dalam menghafalkan Al-Qurán agar terlebih dahulu memahami karakteristik anak dan mempelajari langkah-langkah yang benar dan tepat sehingga bisa membantu anak memiliki rasa cinta terhadap Al-Qurán serta siap menghafalkannya.

\section{DAFTAR PUSTAKA}

Abd-i'r-Rahman, Abu. 1997. Pedoman Menghayati dan Menghafal Al Quran (diterjemahkan oleh Mohammad Handoko Imam Prakoso). Jakarta: Hadi Press.

Al Hafidz, Ahsin W. 2009. Bimbingan Praktis Menghafal Al Quran. Jakarta: Bumi Aksara.

Al Mundziri, Imam. 2003. Ringkasan Shahih Muslim (diterjemahkan oleh Achmad Zaidun). Jakarta: Pustaka Amani.

An Naisabury. 1992. Shahih Muslim Juz I (diterjemahkan oleh Adib Bisri Mustofa). Semarang: As Syifa.

Aziz, Moh. Ali. 2012. Mengenal Tuntas Al Quran. Surabaya: Imtiyaz.

Fauzan dan Wajdi. 2010. Quantum Tahfizh. Palembang: YKM Press.

Al-Quránul Karim (Mushaf Wakaf). 2012. Tangerang: FPQ.

Mahya, Ainun dan Arnina P. 2016. Musa Si Hafiz Cilik Penghafal Al-Qurán. Depok: Huta Publisher. 
Qomariyah, Nurul dan Muhammad Irsyad. 2016. Metode Cepat dan Mudah Agar Anak Hafal Al Quran. Yogyakarta: Semesta Hikmah.

Rasyid, Muhammad Makmun. 2015. Kemukjizatan Menghafal Al Quran, Jakarta: PT Elex Media Komputindo.

Rauf, Abdul Aziz Abdul. 2009. Menghafal Al Quran Itu Mudah. Jakarta: Markaz Al Quran.

Riyadh, Sa’ad. 2016. Metode Tepat Agar Anak Hafal Al-Qurán (alih bahasa Isnaini Bambang H. N dan Arif Manggala). Solo: Pustaka Arafah.

Shihab, M. Quraish. 2007. Mukjizat Al Quran: Ditinjau dari Aspek Kebahasaan, Isyarat Ilmiah, dan Pemberitaan Gaib. Jakarta: Mizan.

Sulaeman, Dina Y. 2008. Doktor Cilik Hafal dan Paham Al Quran. Depok: Pustaka Iman. https://chanelmuslim.com/khazanah/menghafal-quran-saat-usia-40-tahun-inilahpengalaman-prof-dr-ir-kudang-boro-seminar-msc

https:/semangatdakwah.wordpress.com/2015/06/18/8-tips-menghafal-al-quran https:/www.genpi.co/gaya-hidup/37278/takjub-hafiz-cilik-asal-bangka-menorehkanprestasi-di-mesir. 